\title{
Immunological mechanisms involved in psoriasis
}

\author{
Christopher E. M. Griffiths and John J. Voorhees \\ Department of Dermatology, University of Michigan Medical Center, 1910 Taubman Center, \\ Ann Arbor, MI 48109-0314, USA
}

\section{Introduction}

Psoriasis is a common cutaneous disease affecting $2 \%$ of the population. However, there are global variations in incidence in that it is rare in Native Americans and commoner in Northern Europe. The disease is characterized by two main histological features namely epidermal hyperproliferation coupled with an inflammatory infiltrate. Until about 15 years ago experimental dermatologists researching the pathogenesis of psoriasis focused the majority of their attention on the hyperproliferative epidermal compartment and paid scant regard to the inflammatory infiltrate. Indeed, if one had questioned dermatologists in the 1970 s as to whether immunological mechanisms played an integral role in the pathogenesis of psoriasis, it is probable that the overwhelming majority would have answered negatively. As a result of pioneering work performed in Europe and as a consequence of the proven efficacy of the selective $\mathrm{T}$ cell immunosuppressant, cyclosporine, it is now established that psoriasis is indeed immunologically mediated.

This article delineates the various immunological mechanisms believed to be involved in the psoriatic process, debates the relative impact of the contributions each pathway brings to the production of the psoriatic phenotype, and describes how newer immunoregulatory approaches to this disease have helped strengthen the immune-mediation hypothesis.

\section{Genetics}

The evidence that psoriasis is a genetically determined disease is considerable. Approximately one-third of affected individuals have at least one first-degree relative with psoriasis and epidemiological studies from Northern Europe have determined that relatives of psoriatics are three times more likely to suffer from 
the disease than are comparable members of the general population $[53,65]$. A concordance rate of approximately $70 \%$ for monozygotic twins and $15 \%-30 \%$ for dizygotes seems to indicate an autosomal dominant inheritance $[19,33,65$, 101], although the comparatively low concordance rate in monozygotes implies that environmental factors play a key role in the expression of the psoriatic phenotype. Work by Hensler and Christophers [54] categorized psoriatics into two types dependent on age at onset of the disease. In the first type (type I), there is a strong association with the class I MHC antigen HLA-Cw6 which occurs in $85 \%$ of individuals in this group. In the second group (type II) characterized by late age of onset, (60 years old on average) there is a low association with HLACw6. HLA-Cw6 is in linkage disequilibrium with HLA-B13, Bw17, and Bw37 and these three antigens are also more prevalent in psoriatics [89, 101, 103]. The association of psoriasis with HLA antigens provides incidental evidence for the importance of an autoimmune-based concept, particularly the high prevalence of HLA-DR7 and the strong correlation with HLA-B27 in those subjects who have psoriatic sacro-ileitis $[3,40,106]$. Ozawa et al. [83] was unable to find a strong relationship between HLA-Cw6 and psoriasis but did observe that in control, nonpsoriatic subjects a restriction fragment length polymorphism (RFLP) in the 1-alpha-2 domain of $\mathrm{Cw} 6$ was lacking, thereby implying that its presence provided an increased suseptibility to psoriasis.

The increased incidence of the class I MHC molecule HLA-Cw6 or lack of an important RFLP for Cw6 in normal subjects would indicate an importance of $\mathrm{CD}^{+} \mathrm{T}$ cells in psoriasis as these "suppressor" cells only bind and activate in the context of MHC class I. On these grounds it is possible that failure of CD8 suppression of CD4-driven activation may account for the persistence of psoriatic plaques [48]. Unfortunately, it is unlikely to be as simple as this postulation and most probably the role of class II MHC alleles, such as DR7, in recognition of specific antigens is as necessary as class I MHC restriction. Thus, inheritance is probably not one of a single "psoriasis gene"' but likely is multifactorial with environmental factors such as infection holding a controlling interest in phenotypic expression of this genetic predisposition.

\section{The role of $\mathbf{T}$ lymphocytes}

Evidence exists for an impaired cell-mediated immunity in psoriasis [38]. Delayed hypersensitivity to standard prick-test antigens and streptococcal antigen is reduced in psoriatics, and intradermal antigen testing to purified protein derivative (PPD) is characterized by slow resolution of the reaction $[30,60,70]$. In vitro there is an inability of $\mathrm{T}$ cells from psoriatics to proliferate in response to concanavalin A [50]. Perhaps the most striking demonstration of an abnormality (perhaps genetic) in cellular $\mathrm{T}$ lymphocyte function in psoriatics are the reports of a cure of the disease following allogeneic bone marrow transplant [27]. This thesis is buttressed by the converse finding of transmission of psoriasis with allogeneic bone marrow transplant [36].

It was only with the advent of monoclonal antibodies that a rigorous investigation of the components of the dermal and epidermal inflammatory infiltrate in 
psoriatic lesions could be performed. Until then it was known only that the $T$ lymphocyte was a part of the infiltrate but subdivision into CD4, CD8, natural killer cells etc, could not be performed. In 1978 Bjerke et al. [15] demonstrated that the majority of the infiltrate was comprised of T cells of which $\mathrm{CD} 4^{+}$cells formed the major part. Not until the work of Baker and colleagues $[4,100]$ was it apparent that the actual ratio of CD4:CD8 cells was important to both the genesis and resolution of a psoriatic plaque and that activation or HLA-DR expression of these subsets was also critical.

In normal skin there is a small yet significant epidermal traffic of $\mathrm{T}$ cells and these are mainly of the $\mathrm{CD}^{+}$subset [18]. In active, evolving psoriasis of the guttate form there is an intraepidermal influx of activated $\mathrm{DR}^{+} \mathrm{CD} 4^{+} \mathrm{T}$ cells, and the ratio of $\mathrm{CD}^{+}: \mathrm{CD}^{+} \mathrm{T}$ cells is greater than that observed in peripheral blood of the same individuals $[4,100]$. Indeed, the absolute numbers of total and $\mathrm{CD}^{+} \mathrm{T}$ lymphocytes in the blood of psoriatics is lower than in normal subjects [5]. These numbers correlate with disease extent and may be a result of cutaneous sequestration. Spontaneous resolution of guttate psoriasis lesions is predated by an intraepidermal influx of $\mathrm{DR}^{+} \mathrm{CD8}^{+} \mathrm{T}$ cells coinciding with a decrease in $\mathrm{DR}^{+} \mathrm{CD}^{+}$cells $[4,100]$. The same phenomenon is observed during treatment of psoriatic plaques with psoralen ultraviolet A (PUVA) [10]. Indirect evidence for a role for activated $\mathrm{CD}^{+} \mathrm{T}$ lymphocytes in psoriasis accrues from several sources. Psoriatic epidermal keratinocytes exhibit patchy expression of HLA-DR $[4,8]$, and although the extent of this keratinocyte HLA-DR expression is debatable, its presence probably indicates local production of gamma interferon $(\mathrm{IFN}-\gamma)[4,8,14,41]$. IFN- $\gamma$ is produced solely by activated $\mathrm{CD}^{+} \mathrm{T}$ cells and is the only cytokine capable of inducing the expression of HLA-DR $[46,78]$. Other indirect evidence for the presence of activated $\mathrm{CD} 4^{+} \mathrm{T}$ cells is detection of both IFN- $\gamma$ mRNA and protein in psoriatic plaques [14] and keratinocyte expression of IFN- $\gamma$-inducible protein (IP-10) [42] and ICAM-1 [46]. Activation of CD4 ${ }^{+}$ $T$ cells results in expression of the interleukin (IL)-2 receptor (IL-2R) and although there are no reports of IL-2 in psoriatic plaques there are increased levels of IL-2R in suction blister fluid [95].

Support for the importance of $\mathrm{T}$ lymphocytes in the induction and maintenance of psoriatic plaques comes from evidence derived from the efficacy in this disease of the relatively $\mathrm{T}$ cell-specific immunosuppressant cyclosporine. This evidence will be presented later in the chapter.

In the regrettable absence of a good animal model for psoriasis, researchers must utilize early stages of the disease itself for investigation. The Koebner phenomenon which is the ability of traumatized, uninvolved psoriatic skin to develop psoriasis is a useful model for the early events in the genesis of a psoriatic plaque. Koebnerization occurs in only $25 \%$ of psoriatics at any one time and is entirely dependent on disease activity [32]. In subjects who are Koebner positive there is evidence that the epidermal CD4:CD8 ratio in uninvolved skin is significantly higher than in those who are Koebner negative [7]. The increase in $\mathrm{T}$ cell subset ratio is mainly contributed to by a decrease in $\mathrm{CD}^{+}$cells implying a removal of suppression and subsequent triggering of the response threshold.

Although difficult to place in the context of the pathogenesis of psoriasis, it is certain that humoral factors play a role. Stankler [92] made the salient observa- 
tion that serum from patients recovering from active psoriasis had an inhibitory effect on the Koebner reaction and a healing action when injected into active lesions. This was contrasted to the non-inhibitory effect of serum from subjects with ongoing, active psoriasis.

\section{The role of antigen-presenting cells}

Psoriatic epidermis contains increased numbers of $\mathrm{CD} 1^{-} \mathrm{DR}^{+}$cells, whereas there is debate as to the number of $\mathrm{CD} 1^{+} \mathrm{DR}{ }^{+}$Langerhans cells, with views varying from no difference from that found in normal or uninvolved psoriatic skin to increased or decreased numbers as compared to normal. The ability of psoriatic epidermal cell suspensions to stimulate autologous $T$ cell activation and proliferation seems to be dependent on this $\mathrm{CD}^{-} \mathrm{DR}^{+}$subset [2]. Differing views exist as to the nature of these $\mathrm{CD1}^{-} \mathrm{DR}^{+}$cells. They may be a heterogeneous group of macrophages and antigen-presenting cells [2] or, alternatively, immature Langerhans cells $[6,9]$. Certainly the $\mathrm{CD} 1^{-} \mathrm{DR}^{+}$population is not specific for psoriasis but is found in other inflammatory dermatoses [9]. Alternatively, the CD1 surface antigen may be lost on activation of the Langerhans cell or in the presence of IFN- $\gamma$ and the $\mathrm{CDI}^{-} \mathrm{DR}^{+}$group may represent activation and heightened antigen-processing capacity of resident Langerhans cells.

The dermis, although admittedly a more difficult cutaneous compartment to study than epidermis, has received little attention as far as antigen-processing capabilities are concerned. Dermal Langerhans cells are increased in psoriatic relative to normal skin and are found clustered around the vessels of the dermal papillae [17]. This observation has been made in other inflammatory dermatoses such as allergic contact dermatitis and cutaneous $\mathrm{T}$ cell lymphoma $[11,68]$. A recently described putative dermal antigen-presenting cell which resides in the upper papillary dermis and perivascular locale is the Factor XIIIA-positive dermal dendrocyte [52]. In psoriasis, the dermal dendrocytes are increased in number and appear to be activated by virtue of increased dendricity and DR positivity $[20,79]$. These observations indicate a propensity for heightened dermal processing of antigen and possibly cytokine production in psoriasis.

\section{The role of cytokines}

Cytokines are small, cell-derived polypeptides which serve as intercellular chemical messengers. Initially believed to be secreted solely by lymphocytes and monocytes it is now recognized that virtually all cell types found within the skin are capable of producing these molecules. A most significant advance in our understanding of the cutaneous cytokine network came with the recognition that the keratinocyte is not merely an inactive, protective coating to the skin but is an active component of the skin immune system imbued with cytokine-secreting capacity [13]. The availability of sensitive assays, monoclonal antibodies and molecular techniques such as the polymerase chain reaction (PCR) have facilitated our ability to detect cytokines within the skin. Unfortunately, with the relentless 
discovery of new cytokines comes the heightened complexity of understanding how they interact with one another to maintain a homeostatic cutaneous milieu or initiate and perpetuate a disease process such as psoriasis.

IL-1 with its ability to induce expression of endothelial adhesion molecules ICAM-1, ELAM-1, and VCAM-1 [47] and its capabilities of mononuclear cell chemotaxis and induction of keratinocyte proliferation would appear a good candidate for elevation in psoriasis [3]. Somewhat unexpectedly, activity of this interleukin in psoriasis is reduced as compared with normal or uninvolved psoriatic skin [23]. The observed reduction in IL-1 activity is a result of several compounding factors, namely reduced levels of IL-1 $\alpha$, the presence of a functionless form of IL- $\beta$ (although protein levels are increased) and the appearance of an IL-1 inhibitor in psoriasis $[23,51]$. The reduced levels of IL-1 activity in chronic plaque psoriasis may be attributable to consumption of IL-1 during evolution of the lesion and thus research directed at early, evolving psoriatic lesions could reveal increased IL-1 activity at this critical time.

IL-2 is produced by activated $\mathrm{CD} 4^{+} \mathrm{T}$ cells and the presence of soluble IL-2R is indicative of activation. It is surprising that detection of this cytokine has not been reported in psoriatic skin. Suction blister assays and immunoperoxidase studies of cryostat sections have demonstrated increased levels of IL-2R in involved but not uninvolved psoriatic skin implying prior $\mathrm{T}$ cell activation [95]. Increased levels of soluble IL-2R have been detected in both atopic dermatitis and psoriasis [58, 59]. The report by Lee et al. [62] that intravenous IL-2 used for the treatment of carcinoma produced marked flaring of incidental psoriasis in two subjects indicates that IL-2 may be of prime importance in the initiation of a psoriatic response. As with IL-1 the absence of IL-2 in chronic, stable plaques of psoriasis may warrant investigation of the evolving lesion with its concomitant influx of activated $\mathrm{CD}^{+}{ }^{+} \mathrm{T}$ cells.

IL-6 is produced by fibroblasts, keratinocytes, $T$ cells and macrophages and is known to be capable of stimulating keratinocyte proliferation [48]. Increased levels of IL-6 mRNA and protein have been found in both psoriatic plaques [48] and sera and levels of IL-6 protein are increased in psoriatic keratinocytes in vitro [76].

IL-8, previously known as neutrophil-activating peptide or neutrophilactivating factor, was first described as a chemotactic agent for neutrophils but is now recognized as a particularly potent $T$ lymphocyte chemoattractant [61]. IL-8 is produced by keratinocytes, fibroblasts, and lymphocytes and is capable of inducing keratinocyte proliferation in vitro [88]. With this psorigenic capacity it is not surprising that IL-8 protein and mRNA have been observed in psoriatic plaques $[21,37,81]$ and it is possible that this cytokine plays an important pathogenic role.

Tumor necrosis factor-alpha (TNF- $\alpha$ ) has been demonstrated immunohistologically in the dermis of psoriatic plaques and is primarily localized to dermal dendrocytes with limited expression by Langerhans cells [81]. PCR of isolated psoriatic epidermis, however, did not demonstrate TNF- $\alpha$ mRNA [14], although TNF- $\alpha$ protein has been variously reported as being either elevated or decreased in psoriatic serum $[39,73]$. Indirect evidence for the presence of TNF- $\alpha$ is the presence of TNF- $\alpha$-inducible molecules such as transforming growth factor- $\alpha$ 
(TGF- $\alpha$ ) [28, 99] and IL-8 as well as endothelial expression of ICAM-1, VCAM-1 and ELAM-1 and keratinocyte expression of ICAM-1; TNF- $\alpha$ is the only cytokine known to induce this pattern of adhesion molecule expression [47]. Furthermore, angiogenesis which is an important component of psoriatic plaques, has been shown to be inducible by macrophage-derived TNF- $\alpha$ [63]. Epidermal changes are known to precede angiogenesis in advancing psoriatic plaques [84] and epidermal-derived angiogenic factors such as TNF- $\alpha$ may be responsible for this observation [67, 105]. Nickoloff [78] has proposed an elaborate thesis based upon the presence of TNF- $\alpha$ in psoriasis and has proposed this cytokine as the orchestrator of the disease process. However, systemically administered TNF- $\alpha$ is reported to clear psoriasis $[24,96]$ and injection of this cytokine into mouse tail inhibits keratinocyte proliferation [74]. It may be that supraphysiological levels of TNF- $\alpha$ overload and consequently down-regulate its receptors leading to a paradoxical inhibitory effect and consequent disease resolution.

Of all the cytokines measured so far in psoriasis, the candidate most likely to be central to the $\mathrm{T}$ cell-mediated paradigm for this disease is IFN- $\gamma$. IFN- $\gamma$ is produced solely by activated $\mathrm{CD}^{+}{ }^{+} \mathrm{T}$ cells and indirect evidence for its existence in psoriatic plaques is keratinocyte expression of ICAM-1, HLA-DR, and IP-10 [41, 42, 44, 90]. PCR examination of epidermal sheets derived from psoriatic lesions reveals the presence of mRNA for IFN- $\gamma$, whereas this cytokine is absent in normal skin [14]. IFN- $\gamma$ protein has been demonstrated in fluid from suction blisters raised on involved but not uninvolved psoriatic skin $[16,95]$ and is elevated in serum from psoriatic patients [39]. By comparison with normal keratinocytes, psoriatic keratinocytes are less sensitive to the growth inhibitory effects of IFN- $\gamma$ in culture and are less disposed to expression of HLA-DR and ICAM-1 [8, 80]. These observations indicate that psoriatic keratinocytes are hyporesponsive to IFN- $\gamma$. During the course of treating psoriatic arthritis with subcutaneous injections of IFN- $\gamma$, it was observed in 10 of 42 patients that punctate, psoriatic foci were induced at the sites of injection of IFN- $\gamma$ but not at the sites of vehicle injection [34]. Furthermore, injection of IFN- $\gamma$ in normal subjects did not evoke this response. This observation is circumstantial evidence for an integral role for IFN- $\gamma$ in psoriasis.

$\mathrm{TGF}-\alpha$ is a potent inducer of keratinocyte hyperproliferation and is overexpressed in psoriatic plaques at both the mRNA and protein levels [28, 99]. The receptor for TGF- $\alpha$ (TGF- $\alpha-\mathrm{R} / \mathrm{EGF}-\mathrm{R})$ is increased in psoriatic epidermis [75]. Keratinocyte production of TGF- $\alpha$ can be induced by IFN- $\gamma[80]$ and IL-6 in vitro. It appears that increases in TGF- $\alpha$ and subsequent epidermal hyperproliferation do not occur at the expense of a decrease in the growth-inhibiting cytokine TGF$\beta_{1}$, as levels of this molecule appear to be the same in normal and psoriatic skin [28].

\section{The role of an adhesion molecules}

The discovery of adhesion molecules pertinent to cutaneous biology came with the observation that ICAM-1 expression could be induced on keratinocytes and 
endothelial cells by TNF- $\alpha$ and IFN- $\gamma$ [25]. Since then additional endothelial adhesion molecules have been described and there is little doubt that their interactions with mononuclear cells are pivotal to our understanding of cutaneous trafficking and inflammation. In normal, uninflamed skin, ICAM-1 is the sole adhesion molecule expressed and then only on endothelium [46, 90]. The expression of ICAM-1 by keratinocytes is indicative of the presence of TNF- $\alpha$ and/or IFN- $\gamma$, although protein kinase $\mathrm{C}$ agonists such as urushiol can directly induce keratincyte expression of ICAM-1 [44]. Endothelial expression of ICAM-1 can be upregulated by TNF- $\alpha$, IFN- $\gamma$, IL-1 and lipopolysaccharide. The two adhesion molecules peculiar to endothelium, ELAM-1 and VCAM-1, are only induced by IL-1 and TNF- $\alpha$ [78].

In psoriatic epidermis keratinocyte ICAM-1 is focally expressed, particularly in the region immediately overlying the dermal papillae and ICAM-1-expressing keratinocytes are observed closely juxtaposed to infiltrating LFA-1-expressing lymphocytes [46]. ICAM-1, ELAM-1, and VCAM-1 are all expressed by psoriatic endothelium, thereby implying the presence of IL-1 and/or TNF- $\alpha$ [49]. ELAM-1 binds neutrophils, monocytes and memory $\mathrm{T}$ cells. The receptor for ELAM-1 expressed by a distinct skin-homing subset of memory $\mathrm{T}$ cells is the cutaneous lymphocyte-associated antigen (CLA) [85]. This observation coupled with the finding that ELAM-1 is preferentially expressed in skin and synovium [82] may be of considerable importance to the pathogenesis of inflammatory skin disease, especially pertinent in the case of psoriasis with its associated arthritis.

\section{New therapies as investigatory tools in psoriasis}

The ability of selective immunosuppressive agents to suppress the cutaneous manifestations of psoriasis has been salutory in strengthening belief in the immunemediated hypothesis of this disease. Perhaps the one drug which has done most to further this hypothesis has been cyclosporine. In 1979, Mueller and Hermann [72] made a salient serendipitous observation during a study of the use of oral cyclosporine for arthritis. In this study four subjects happened to have psoriatic arthritis and their concomitant cutaneous plaques resolved rapidly after initiation of therapy. Subsequently, open and double-blind studies of cyclosporine in psoriasis have confirmed this observation $[30,43,45]$. What then is the significance of these observations to our understanding of the pathogenesis of psoriasis?

Cyclosporine has a mechanism of action directed mainly at the $\mathrm{CD}^{+} \mathrm{T}$ lymphocyte and is known to inhibit its production of IL-2 and IFN- $\gamma[22,29$, 57]. Inhibition occurs as a result of cyclosporine complexing with its receptor, cyclophilin, which is a member of the peptidyl-prolyl cis-trans isomerase group of enzymes which are important in protein re-folding [94]. The cyclosporine/ cyclophilin complex subsequently inhibits a calcium-activated protein, calcineurin phosphatase, and blocks translocation from the cytoplasm to the nucleus of a component of nuclear factor of activated T cells (NFAT) which ultimately leads to inhibition of $\mathrm{T}$ cell activation [22, 31, 64]. Cyclosporine has no direct antiproliferative effect on keratinocytes except under non-physiological, low 
calcium, serum-free conditions where the concentration of cyclosporine exceeds that measured in skin during systemic treatment of psoriasis [35]. Lamellar ichthyosis is an autosomal recessive disease chracterized by epidermal hyperproliferation which occurs in the absence of any appreciable lymphocytic infiltrate. Treatment of this condition with cyclosporine has been unsuccessful [55], an observation which provides strong but circumstantial evidence that the hyperproliferative keratinocyte is not cyclosporine's primary target.

When psoriasis is treated with systemically administered cyclosporine a large reduction in $\mathrm{CD}^{+}$and $\mathrm{CD} 8^{+} \mathrm{T}$ cells occurs within the plaques but only a small decrease in the $\mathrm{DR}^{+} \mathrm{CD} 4^{+} \mathrm{T}$ cell subset [6]. This observation implies that, although activated $\mathrm{DR}^{+} \mathrm{CD} 4^{+}$cells are still present, they are in effect paralyzed and unable to produce cytokines capable of perpetuating the psoriatic process. The failure of topically applied cyclosporine in the treatment of psoriasis [43] necessitated intralesional studies of this drug in chronic plaque psoriasis, an approach which produces resolution of the injected plaques over a period of 4 weeks. Sequential biopsies taken during those studies led to seminal observations concerning the role of $\mathrm{CD}^{+}{ }^{+} \mathrm{T}$ cells. Prior to any clinical improvement, a reduction occurs in numbers of intraepidermal $\mathrm{DR}^{+} \mathrm{CD} 4^{+} \mathrm{T}$ cells, however, immediate to this event there is a $67 \%$ reduction in keratinocyte ICAM-1 expression implying inhibition of $\mathrm{DR}^{+} \mathrm{CD} 4^{+} \mathrm{T}$ cell-derived $\operatorname{IFN}-\gamma[43,56]$. It is postulated that a reduction in keratinocyte ICAM-1 expression would free LFA-1-expressing $T$ cells from their apposition to keratinocytes and allow their return to the dermis and hence to recirculation. Other cytokines (such as IL-6) derived from T cells could also be inhibited by cyclosporine ultimately leading to resolution. FK506 is a macrolide antibiotic, structurally unrelated to cyclosporine but with an extremely similar mechanism of action and binding protein [98], which has been reported successful in the treatment of psoriasis [1]. The efficacy of this macrolide antibiotic further emphasizes the $T$ cell-mediated nature of psoriasis particularly, as FK506 also has no direct effect on keratinocytes [91].

Newer, more specific therapies targeted at the $T$ cell and the $T$ cell receptor are being introduced into the treatment of autoimmune disease and both by design and by chance these have been used in psoriasis. Monoclonal antibodies targeted at the T cell, e. g., anti-CD3, are being used for the treatment of multiple sclerosis. One such patient also suffering from psoriasis was treated with anti-CD3 and a marked improvement in psoriasis was noted [102]. More specific antibodies directed against CD4, are also in use. To date, there are three reports totalling five patients which indicate that systemically administered anti-CD4 monoclonal antibodies will clear or markedly improve psoriasis [77, 86, 87]. As with all therapies for psoriasis, the disease relapses after cessation of treatment.

Many all-encompassing theories have been proposed for the immunopathogenesis of psoriasis and only time will dictate their accuracy $[3,12,78]$. For any theory to be viable, it should take into account the following points: inheritance, Koebner phenomenon, epidermal hyperproliferation, inflammation and angiogenesis.

Antigen presentation to cutaneous $\mathrm{T}$ cells by Langerhans cells, dermal dendrocytes, and possibly keratinocytes most likely motivates the psoriatic process in genetically predisposed individuals. The most attractive candidates (on current 
knowledge) for putative initiating antigens are members of the $\beta$-hemolytic streptococcal family [97]. The propensity of streptococcal infection (particularly of the $\beta$-hemolytic sub-type) to exacerbate chronic plaque psoriasis and initiate guttate psoriasis has been widely reported [97, 104]. Additionally, systemic antibiotics, e. g., penicillin, are known to prevent recurrence of the disease process. McFadden [69] has hypothesized that the observed reduction in delayed-type hypersensitivity to streptococcal antigen in psoriatics may serve as a protective mechanism against scarlet fever. The $\mathbf{M}$ protein of streptococci has the ability to behave as a superantigen, thereby activating $\mathrm{T}$ cells without class II MHC restriction. Molecular mimickry and cross reactivity between streptococcal protein and keratins may also account for perpetuation [71, 93]. Viral particles are also implicable as has been learnt from the exacerbation of psoriasis by AIDS most probably as a result of presentation of HIV antigens by Langerhans cells and dermal dendrocytes to $\mathrm{T}$ lymphocytes within the skin [26, 66]. Thus, in AIDS patients with psoriasis there is a somewhat paradoxical vigorous immune response taking place within the skin occurring in the face of systemic immunosuppression.

Activation of Langerhans cells and dermal dendrocytes would initiate production of IL-1 and TNF- $\alpha$ both of which are capable of inducing ELAM-1, ICAM-1, and VCAM-1 on dermal capillary endothelium. TNF- $\alpha$ can further induce TNF- $\alpha$ production by keratinocytes in both autocrine and paracrine fashions and stimulate IL-8 production by keratinocytes. In addition, TNF- $\alpha$ and other epidermal-derived cytokines would stimulate angiogenesis. Endothelial adhesion molecule expression, particularly ELAM-1, would allow binding of circulating $T$ cells most probably of the memory, CLA-expressing subset. IL-8 and IL-1 derived both from keratinocytes and dermal dendrocytes may attract these adherent $T$ cells away from the vascular wall and towards dermal antigen-presenting cells. Subsequent to this migration and antigen-processing, the $\mathrm{T}$ cells are activated. In all likelihood $\mathrm{T}$ cells could be activated at sites distal to the skin, such as lymph nodes and tonsils and then migrate to the skin in a fully primed state, thus obviating the need for cutaneous antigen presentation. Activation releases a cascade of cytokines including IFN- $\gamma$ which in turn up-regulates ICAM-1 on keratinocytes allowing close $\mathrm{T}$ cell/keratinocyte binding and subsequent interactions. Once the amplification process has begun, further production of cytokines such as IL-6, IL-8, and TGF- $\alpha$ will promulgate epidermal hyperproliferation and overwhelming of the negative feedback imposed by $\mathrm{CD}^{+} \mathrm{T}$ cells.

The Koebner phenomenon may be explicable by direct epidermal injury (which is necessary for this process) releasing keratinocyte-derived cytokines, such as IL- 1 and TNF- $\alpha$, capable of up-regulation of endothelial and keratinocyte adhesion molecules and initiation of $T$ cell trafficking without recourse to antigen presentation.

The defect in psoriasis, which most likely is multifactorial, may reside in the keratinocyte, Langerhans cell or $\mathrm{T}$ cell. However, to explain the decreased sensitivity of psoriatic keratinocytes to IFN- $\gamma$, the enhanced antigen-presenting capacity of psoriatic Langerhans cells, the defects in cellular immunity and the "cure" of psoriasis by allogeneic bone marrow transplant, it is possible that the genetic defects are expressed in multiple cell types and that no abnormality in a single cell type can account for all the features of psoriasis. 


\section{Conclusions}

The past decade has borne witness to tremendous advances in our knowledge of the pathogenesis of psoriasis and the weight of evidence is now on the side of the $T$ cell as being an integral mediator of this process. Advances in molecular technology have enabled direct in vivo measurement of cytokines and, although no animal model exists for the study of psoriasis, the use of cyclosporine has served as an excellent investigatory tool. The utilization of therapeutics to study psoriatic mechanisms is an unusual approach in that one must derive conclusions from disappearance of measurable factors such as cytokines and assume that these same factors are vital to the initiation and maintenance of a psoriatic plaque. Studying disease evolution using the Koebner phenomenon or relapse following treatment would supply a more accurate picture of initiating events. Based on the immune hypothesis, therapeutic modalities which are now entering the arena include $T$ cell vaccination, particularly if psoriasis-specific $T$ cell receptor $V_{\beta}$-restricted clones can be isolated from psoriatic plaques.

There is little doubt that by the end of this century, cutaneous biologists will have built substantially on the immunological foundation laid by the early work outlined here. Most likely the genetic contribution(s) to the manifestations of psoriasis will be more fully elucidated and that gene therapy will carry more than a futuristic promise. At least for the present we believe that such significant advances have been made that the majority of dermatologists if questioned nowadays as to whether psoriasis is an immunologically-mediated disease would answer in the affirmative.

\section{References}

1. Ackerman C, Abu-Elagd A, Venkatoramanan K, Fung J, Todo S, Starzl T, Jegasothy B (1991) Recalcitrant psoriasis and pyoderma gangrenosum treated with FK506 (abstract). J Invest Dermatol 96: 536

2. Baadsgaard O, Gupta AK, Taylor RS, Ellis CN, Voorhees JJ, Cooper KD (1989) Psoriatic epidermal cells demonstrate increased numbers and function of non-Langerhans antigen-presenting cells. J Invest Dermatol 92: 190

3. Baker BS, Fry L (1991) The immunology of psoriasis. Br J Dermatol 126: 1

4. Baker BS, Swain AF, Fry L, Valdimarsson H (1984) Epidermal T lymphocytes and HLA-DR expression in psoriasis. Br J Dermatol 110: 555

5. Baker BS, Swain AF, Valdimarsson H, Fry L (1984) T cell subpopulations in the blood and skin of patients with psoriasis. Br J Dermatol 110: 37

6. Baker BS, Griffiths CEM, Lambert S, Powles AV, Valdimarsson H, Fry L (1987) The effects of cyclosporin $\mathrm{A}$ on $\mathrm{T}$ lymphocytes and dendritic cell subpopulations in psoriasis. $\mathrm{Br} \mathrm{J}$ Dermatol 116: 503

7. Baker BS, Powles AV, Lambert S, Valdimarsson H, Fry L (1988) A prospective study of the Koebner reaction and T lymphocytes in uninvolved psoriatic skin. Acta Derm Venereol (Stockh) 68: 430

8. Baker BS, Powles AV, Valdimarsson H, Fry L (1988) An altered response by psoriatic kerationocytes to gamma interferon. Scand J Immunol 28: 735

9. Baker BS, Lambert S, Powles AV (1988) Epidermal $\mathrm{DR}^{+} \mathrm{T}^{-}$dendritic cells in inflammatory skin diseases. Acta Derm Venereol (Stockh) 68: 209 
10. Baker BS, Swain AF, Griffiths CEM, Leonard JN, Fry L, Valdimarsson H (1985) Epidermal T lymphocytes and dendritic cells in chronic plaque psoriasis: the effects of PUVA treatment. Clin Exp Immunol 61: 526

11. Bani D, Moretti S (1987) Are Langerhans cells usual components of the dermal infiltrate of mycosis fungoides? Arch Dermatol Res 279: 561

12. Barker JNWN (1991) The pathophysiology of psoriasis. Lancet 338: 227

13. Barker JNWN, Mitra RS, Griffiths CEM, Dixit VM, Nickoloff BJ (1991) Keratinocytes as initiators inflammation. Lancet 337: 211

14. Barker JNWN, Karabin GD, Stoof TJ, Sarma VJ, Dixit VM, Nickoloff BJ (1991) Detection of interferon-gamma mRNA in psoriatic epidermis by polymerase chain reaction. J Dermatol Sci 2: 106

15. Bjerke JR, Krough HK, Matre R (1978) Characterisation of mononuclear cell infiltrate in psoriatic lesions. J Invest Dermatol 71: 340

16. Bjerke JR, Livden JK, Degre M, matre R (1983) Interferon in suction blister fluid from psoriatic lesions. Br J Dermatol 108: 295

17. Bos JD, Van Garderen ID, Krieg SR, Poulter LW (1986) Different in situ distribution patterns of dendritic cells having Langerhans (T6+) and interdigitating (RFD1 +) cell immunophenotype in psoriasis, atopic dermatitis and other inflammatory dermatoses. J Invest Dermatol 87: 358

18. Bos JD, Zonneveld I, Das PK, Krieg SR, Vanderloss CM, Kapsenberg ML (1987) The skin immune system (SIS): distribution and immunophenotype of lymphocyte subpopulations in normal skin. J Invest Dermatol 88: 569

19. Brandrup F, Hauge M, Henningsen K, Eriksen B (1978) Psoriasis in an unselected series of twin pairs. Arch Dermatol 114: 874

20. Cerio R, Griffiths CEM, Cooper KD, Headington JT, Nickoloff BJ (1989) Characterization of factor XIII-positive dermal dendritic cells in normal and inflamed skin. Br J Dermatol 121: 421

21. Christophers E, Schroder JM, Mrowietz U (1989) Identification of two endogenous neutrophilactivating peptides in psoriatic skin and inflammatory cells: C5a and NAP-1. Dermatologica 179 [Suppl 1]: 9

22. Cooper KD, Voorhees JJ, Fisher GJ, Chan LS, Gupta AK, Baadsgaard O (1990) Effects of cyclosporine on immunologic mechanisms in psoriasis. J Am Acad Dermatol 23: 1318

23. Cooper KD, Hammerberg C, Baadsgaard O, Elder JT, Chan LS, Sauder DN, Voorhees JJ, Fisher GJ (1990) IL-1 activity is reduced in psoriatic skin: decreased IL-1 $\alpha$ and increased nonfunctional IL- $\beta$. J Immunol 144: 4593

24. Creaven PS, Stoll HL (1991) Response to tumor necrosis factor in two cases of psoriasis. J Am Acad Dermatol 24: 735

25. Dustin ML, Rothlein R, Bhan AK, Dianarello CA, Springer TA (1986) Induction by IL-1 and interferon $\gamma$ : tissue distribution, biochemistry, and function of a natural adherence molecule (ICAM-1). J Immunol 137: 245

26. Duvic M, Johnson T, Rapini RP, Freese T, Rios A (1987) Acquired immunodeficiency syndrome-associated psoriasis and Reiter's syndrome. Arch Dermatol 123: 1622

27. Eedy DJ, Burrows D, Bridges JM, Jones FGC (1990) Clearance of severe psoriasis after allogeneic bone marrow transplantation. Br Med J 300: 908

28. Elder JT, Fisher GJ, Lindquist PB, Bennett GL, Pittelkow MR, Coffey RJ, Ellingsworth L, Derynk R, Voorhees JJ (1989) Overexpression of transforming growth factor alpha in psoriatic epidermis. Science 243: 811

29. Elliott JF, Lin Y, Mizel SB, Bleackley RC, Harnish DC, Paetkau V (1984) Induction of interleukin 2 messenger RNA inhibited by cyclosporine A. Science 226: 1439

30. Ellis CN, Fradin MS, Messana JM, Brown MD, Siegel MT, Hartley AH, Rocher LL, Wheeler S, Hamilton TA, Parrish TG, Ellis-Madu M, Duell E, Annesley TM, Cooper KD, Voorhees JJ (1991) Cyclosporine for plaque type psoriasis. Results of a multidose, double-blind trial. N Engl J Med 324: 277

31. Emmel EA, Verweije CL, Durand DB, Higgins KM, Lacy E, Crabtree GR (1989) Cyclosporin A specifically inhibits function of nuclear proteins involved in T cell activation. Science 246: 1617

32. Eyre RW, Krueger GG (1982) Response to injury of skin involved and uninvolved with psoriasis and its relation to disease activity: Koebner and "reverse" Koebner reactions. Br J Dermatol 106: 153 
33. Farber EM, Bright RD, Nall ML (1968) Psoriasis: a questionnaire survey of 2,144 patients. Arch Dermatol 98: 248

34. Fierlbeck G, Rasner G, Muler G (1990) Psoriasis induced at injection site by recombinant gamma interferon. Arch Dermatol 126: 351

35. Fisher GJ, Duell EA, Nickoloff BJ, Annesley TM, Kowalke JK, Ellis CN, Voorhees JJ (1988) Levels of cyclosporine in epidermis of treated psoriasis patients differentially inhibit growth of keratinocytes cultured in serum free versus serum-containing media. J Invest Dermatol 91: 142

36. Gardembas-Pain M, Irah N, Foussard C, Boassom M, Andre JPS, Verret JL (1990) Psoriasis after allogenic bone marrow transplantation. Arch Dermatol 126: 1523

37. Gillitzer R, Berger R, Mielke V, Muller C, Molff K, Stingl G (1991) Upper keratinocytes of psoriatic skin lesions express high levels of NAP-1/IL-8 mRNA in situ. J Invest Dermatol 97: 1

38. Goan S-R, Volk HD, Eichhorn I, Diezel W (1986) Differences in interferon gamma response of psoriatic lymphocytes to stimulation with various mitogens. Biomed Biochim Acta 45: 903

39. Gomi T, Shiohara T, Munakata T, Imanish K, Nagashima M (1991) Interleukin $1 \alpha$, tumor necrosis factor- $\alpha$ and interferon- $\gamma$ in psoriasis. Arch Dermatol 127: 827

40. Gottlieb AB, Krueger JG (1990) HLA region genes and immune activation in the pathogenesis of psoriasis. Arch Dermatol 126: 1083

41. Gottlieb AB, Lifshitz B, Fu SM, Staiano-Coico L, Wang CY, Carter DM (1986) Expression of HLA-DR molecules by keratinocytes and presence of Langerhans cells in the dermal infiltrate of active psoriatic plaques. J Exp Med 164: 1013

42. Gottlieb AB, Luster AD, Posnett DN, Carter DM (1988) Detection of a gammainterferon-induced protein (IP-107) in psoriatic plaques. J Exp Med 168: 941

43. Griffiths CEM (1990) Systemic and local administration of cyclosporine in the treatment of psoriasis. J Am Acad Dermatol 23: 1242

44. Griffiths CEM, Nickoloff BJ (1989) Keratinocyte intercellular adhesion molecule-1 (ICAM-1) expression precedes dermal $\mathrm{T}$ lymphocytic infiltration in allergic contact dermatitis (Rhus dermatitis). Am J Pathol 135: 1045

45. Griffiths CEM, Powles AV, McFadden J, Baker BS, Valdimarsson H, Fry L (1989) Long term cyclosporin A for psoriasis. Br J Dermatol 120: 253

46. Griffiths CEM, Voorhees JJ, Nickoloff BF (1989) Characterization of intercellular adhesion molecule-1 and HLA-DR expression in normal and inflamed skin. Modulation by recombinant gamma interferon and tumor necrosis factor. J Am Acad Dermatol 20: 617

47. Griffiths CEM, Barker JNWN, Kunkel S, Nickoloff BJ (1991) Modulation of leukocyte adhesion molecules, a $\mathrm{T}$ cell chemotaxin and a regulatory cytokine in allergic contact dermatitis (rhus dermatitis). Br J Dermatol 124: 519

48. Grossman RM, Krueger J, Yourish D, Granelli-Pigerno A, Murphy DP, May LT, Kupper TS, Sehgal PB, Gottlieb AB (1989) Interleukin-6 (IL-6) is expressed in high levels in psoriatic skin and stimulates proliferation of cultured human keratinocytes. Proc Natl Acad Sci USA 86: 6367

49. Groves RW, Allen MH, Barker JNWN, Haskard DO, MacDonald DM (1991) Endothelial leukocyte adhesion molecule-1 (ELAM-1) expression in cutaneous inflammation. $\mathrm{Br} \mathbf{J}$ Dermatol 124: 117

50. Guilhou J-J, Clot J, Meynadier J (1977) T cell defect in psoriasis: further studies on membrane markers and $\mathrm{T}$ cell functions from 60 patients. Arch Dermatol Res 620: 163

51. Hammerberg C, Fisher G, Baadsgaard O, Voorhees JJ, Cooper KD (1989) Characterization of IL-1 and inhibitor in psoriatic and normal skin (abstract). J Invest Dermatol 92: 439

52. Headington JT (1986) The dermal dendrocyte. In: Callen JP, Dahl MV, Golitz LD (eds) Advances in Dermatology, vol 1. Year Book Medical Publishers, Chicago, pp 159-171

53. Hellgren L (1987) Psoriasis. Almquist and Wiksell, Stockholm

54. Henseler T, Christophers E (1985) Psoriasis of early and late onset: characterization of two types of psoriasis vulgaris. J Am Acad Dermatol 13: 450

55. Ho VC, Gupta AK, Ellis CN, Cooper KD, Nickoloff BJ, Voorhees JJ (1988) Cyclosporine for lamellar ichthyosis. Arch Dermatol 125: 511

56. Ho VC, Griffiths CEM, Ellis CN, Gupta AD, McCuaig CC, Nickoloff BJ, Cooper KD, Hamilton TA, Voorhees JJ (1990) Intralesional cyclosporine A in the treatment of psoriasis. J Am Acad Dermatol 22: 94

57. Kalman VK, Klimpel GR (1983) Cyclosporine A inhibits the production of gamma interferon 
(IFN-gamma), but does not inhibit production of virus-induced IFN-alpha/beta. Cell Immunol $78: 122$

59. Kemmett D, Symons JA, Colver GB, Duff GW (1989) Serum soluble interleukin 2 receptor in psoriasis. Acta Derm Venereol (Stockh) 70: 264

60. Krueger GG, Hill HR, Jederberg WW (1978) Inflammatory and immune cell function in psoriasis: a subtle disorder. J Invest Dermatol 71: 189

61. Larsen CG, Anderson A, Appella E, Oppenheim JJ, Matsushima K (1989) The neutrophilactivating protein (NAP-1) is also chemotactic for T lymphocytes. Science 243: 1464

62. Lee RE, Gaspari AA, Lotze MT, Chang AE, Rosenberg SA (1988) Interleukin 2 and psoriasis. Arch Dermatol 124: 1811

63. Leibovich ST, Polverini PJ, Sheperd HM, Wiseman DM, Shively V, Nuseir N (1987) Macrophage-induced angiogenesis is mediated by tumor necrosis factor $\alpha$. Nature 329: 630

64. Liu J, Farmer JD, Lane WS, Friedman J, Weissman I, Schrieber SL (1991) Calineurin is a common target of cyclophilin, cyclosporin A and FKBP-FK506 complexes. Cell 66: 807

65. Lomholt G (1963) Psoriasis, prevalence, spontaneous course and genetics. BEC Gads Boghandel, Copenhagen

66. Mahoney SE, Duvic M, Nickoloff BJ, Minshall M, Smith LC, Griffiths CEM, Paddock SW, Lewis DE (1991) HIV transcripts identified in HIV-related psoriasis and Kaposi's sarcoma lesions. J Clin Invest 88: 174

67. Malhotra R, Stenn KS, Fernandez LA, Braverman IM (1989) The angiogenic properties of normal and psoriatic skin associate with the epidermis not the dermis. Lab Invest 61: 162

68. Marks JG, Zaino RJ, Bressler MF, Williams JV (1987) Changes in lymphocyte and Langerhans cell populations in allergic and irritant contact dermatitis. Int J Immunol 26: 354

69. McFadden JP (1990). Hypothesis - The natural selection of psoriasis. Clin Exp Dermatol 15: 39

70. McFadden JP, Powles AV, Baker BS, Valdimarsson H, Fry L (1989) Intradermal antigen tests in psoriasis. Acta Derm Venereol (Stockh) 70: 262

71. McFadden JP, Valdimarsson H, Fry L (1991). Immunological cross-reactivity between streptococcal M protein and human skin. Br J Dermatol 125: 443

72. Mueller W, Hermann B (1979) Cyclosporine A for psoriasis. N Engl J Med $301: 555$

73. Murdoch M, Navasaria H, Balkwill F, Trousdale J, Leigh I (1989) Tumor necrosis factor and psoriasis (abstract). Br J Dermatol 119: 46

74. Nagano K, Hori K, Nagane T, Sugawara T, Oh-ishi J, Hayashi H, Watanabe N, Nitsu Y (1990) Effect of tumor necrosis factor in the mouse tail model of psoriasis. Arch Dermatol Res 282: 459

75. Nanney LB, Stoschek CM, Magid M, King LE (1986) Altered epidermal growth factor binding and receptor distribution in psoriasis. J Invest Dermatol 86: 260

76. Neuner P, Urbanski A, Trautinger F, Moller A, Kirnbauer R, Kapp A, Schopf E, Schwarz $T$, Luger TA (1991) Increased IL-6 production by monocytes and keratinocytes in patients with psoriasis. J Invest Dermatol 97: 27

77. Nicholas JF, Chamchick N, Thivolet J, Wijdnes J, Morel P, Revillard JP (1991) CD4 antibody treatment of severe psoriasis. Lancet 338: 321

78. Nickoloff BJ (1991) The cytokine network in psoriasis. Arch Dermatol 127: 871

79. Nickoloff BJ, Griffiths CEM (1990) Lymphocyte trafficking in psoriasis: a new perspective emphasizing the dermal dendrocyte with active dermal recruitment mediated via endothelial cells followed by intra-epidermal $T$ cell activation. J Invest Dermatol 95: 35s

80. Nickoloff BJ, Mitra RS, Elder JT, Fisher GJ, Voorhees JJ (1989) Decreased growth inhibition by recombinant gamma interferon is associated with increased transforming growth factor- $\alpha$ production in keratinocytes cultured from psoriatic lesions. Br J Dermatol 121: 161

81. Nickoloff BJ, Karabin GD, Barker JNWN, Griffiths CEM, Sarma V, Mitra RS, Elder JT, Kunkel SL, Dixit V (1991) Cellular localization of interleukin-8 and its inducer tumor necrosis factor alpha in psoriasis. Am J Pathol 138: 129

82. Nickoloff BJ, Fivenson DP, Griffiths C, Modlin R (1991) Preferential but not unique cutaneous endothelial cell expression of ELAM-1 (abstract). Clin Res 39: 153

83. Ozawa A, Ohkido M, Inako H, Ando A, Tsuji K (1988) Specific restriction fragment length polymorphism on the HLA-C region and susceptibility to psoriasis vulgaris. $\mathrm{J}$ Invest Dermatol 90: 402

84. Parent D, Bernard BA, Desbas C, Heenen M, Darmon MY (1990) Spreading of psoriatic 
plaques: alteration of epidermal differentiation precedes capillary leakiness and anomalies and vascular morphology. J Invest Dermatol 95: 333

85. Picker LJ, Kishimoto TK, Smith CW, Warnock RA, Butcher EC (1991) ELAM-1 is an adhesion molecule for skin-homing T cells. Nature 349: 796

86. Poizot-Martin I, Dhiver C, Mawas C, Olive D, Gastraut JA (1991) Are CD4 antibodies and peptide $\mathrm{T}$ new treatments for psoriasis? Lancet 337: 1477

87. Prinz J, Braun Falco O, Meurer M, Daddona P, Reiter C, Rieber P, Riethmuller G (1991) Chimaeric CD4 monoclonal antibody in treatment of generalised pustular psoriasis. Lancet 338: 320

88. Reusch M, Studtmann K, Schroder MJ (1999) NAP-1/IL-8 is a potent mitogen for human kerationocytes in vitro (abstract). $J$ Invest Dermatol 95: 485

89. Russell TJ, Schultes CM, Juban D (1972) Histocompatability (HLA) antigens associated with psoriasis. N Engl J Med 287: 738

90. Singer J, Tuck DT, Sampson HA, Hall RP (1989) Epidermal keratinocytes express the adhesion molecule intercellular adhesion molecule- 1 in inflammatory dermatoses. J Invest Dermatol 92: 746

91. Somach S, Hebda P, Wartz V, Jegasothy B (1991) The effects of FK506 on keratinocytes (abstract). J Invest Dermatol 96: 580

92. Stankler L (1969) Blood and tissue factors influencing the Koebner reaction in psoriasis. Br J Dermatol 106: 153

93. Swerlick RA, Cunningham MW, Hall NK (1986) Monoclonal antibodies cross-reactive with group A streptococci and normal and psoriatic human skin. J Invest Dermatol 87: 357

94. Takahashi N, Hagano T, Suzuki M (1989) Peptidyl-prolyl cis-trans isomerase is the cyclosporin A-binding protein cyclophilin. Nature 337: 473

95. Takematsu $H$, Tagami $H$ (1990) Interleukin-2, soluble interleukin-2 receptor and interferon gamma in the suction blister fluids from psoriatic skin. Arch Dermatol Res 282: 149

96. Takematsu H, Ozawa H, Yoshimura T, Hara M, Sakakibara A, Oyama J, Tagami H (1991) Systemic TNF administration in psoriatic patients: a promising therapeutic modality for severe psoriasis. Br J Dermatol 124: 209

97. Telfer NR, Chalmers RJC, Whale K, Colman G (1992) The role of streptococcal infection in the initiation of guttate psoriasis. Arch Dermatol 126: 39

98. Thomson AW (1990) FK506 enters the clinic. Immunol Today 11: 35

99. Turbitt ML, Akhurst RJ, White SI, Mackie RM (1990) Localization of elevated transforming growth 1972 alpha in psoriatic epidermis. J Invest Dermatol 95: 229

100. Valdimarsson H, Baker BS, Jonsdottir I, Fry L (1986) Psoriasis: a disease of abnormal keratinocyte proliferation induced by $\mathrm{T}$ lymphocytes. Immunol Today 7: 256

101. Watson W, Cann HM, Farber EM, Nall ML (1972) The genetics of psoriasis. Arch Dermatol 105: 197

102. Weinshenker BG, Bass BH, Ebers GC, Rice GPA (1989) Remission of psoriatic lesions with muromonab-CD3 (orthoclone OKT3) treatment. J Am Acad Dermatol 20: 1132

103. White SH, Newcomer VD, Mickey MR, Terasaki PI (1972). Disturbance of HLA antigen frequency in psoriasis. N Engl J Med 287: 740

104. Winfield JM (1916) Psoriasis as a sequel to acute inflammations of the tonsils: a clinical note. J Cutan Dis 34: 441

105. Wolf JE (1989) Angiogenesis in normal and psoriatic skin. Lab Invest 61: 139

106. Woodrow JC, Ilchysyn A (1985) HLA antigens in psoriasis and psoriatic arthritis. J Med Genet 22: 492 